\title{
THE ROLE OF TRUST IN ONLINE SHOPPING MALLS: DIFFERENT TYPES OF TRUST AND HOW THEY AFFECT CONSUMER INTENTION
}

\author{
Yong Joon Kim \\ Korea Advanced Institute of Science and Technology \\ 291, Daehak-ro, Yuseong-gu, Daejeon, Korea \\ yongjoon.kim@kaist.ac.kr \\ Se Mi Han \\ Korea Advanced Institute of Science and Technology \\ 291, Daehak-ro, Yuseong-gu, Daejeon, Korea \\ sm32@kaist.ac.kr \\ Euehun Lee \\ Korea Advanced Institute of Science and Technology \\ 291, Daehak-ro, Yuseong-gu, Daejeon, Korea \\ euehunlee@kaist.ac.kr
}

\begin{abstract}
This study investigates the mediating role of trust-to-mall and trust-to-transaction as these concepts pertain to consumers' usage intentions of an online shopping mall. In addition, the theory of reasoned action (TRA) and technology acceptance model (TAM) is utilized to explain why perceived usefulness, enjoyment, perceived risk and subjective norm affect consumers' intention to use using structural equation modelling (SEM).
\end{abstract}

Keywords: Trust, Mediating Role, Online Shopping Mall

\section{INTRODUCTION}

The Korea Consumer Agency ${ }^{1}$, which is the largest consumer rights protection organizations in Korea, announced an increased number of consumer claims (2,231 in 2006; 4,076 in $2010 ; 82.7 \%$ increase) about online transactions in 2010. This trend may cause consumers to distrust online transactions, as consumer claims decrease the trust to online shopping $^{2}$. The motivation through which consumers establish trust originates in uncertainty when consumers deal with vendors. Since consumers require cognitive resources causing consumers to desire to build 
up trust to reduce uncertainty and complexity during transactions ${ }^{3}$, they start to trust to reduce usage of cognitive resources. In an online shopping situation, several characteristics of the transactions cause more uncertainty to consumers ${ }^{4,5}$.

Trust related to an internet shopping mall can be divided into transactions and the virtual mall itself by adopting idea in retailing research area $^{6}$. In this study, we followed Pavlou's ${ }^{7}$ definition of trust (p.74,); therefore, TM and TT are the beliefs that consumers can be vulnerable to malls and transactions by respectively considering the two types of trust.

We combined TRA and TAM to find antecedents of the model. Chang and $\mathrm{Chen}^{8}$ found a significant effect of trust of a website on purchase intention.

Hla: TM positively affects INT.

H1b: TT positively affects INT.

We also investigated the effects of PU, ENJ, PR and SN on consumers' intention through trust. Although many studies have shown that PU, ENJ, PR and SN closely associated with intention ${ }^{6,8,9,10}$ in an online shopping context, other studies argue that trust mediates the effect of seller action on consumers' decision- making processes in the relationship marketing context $^{11,12}$.

H2: PU positively affects $T M(a) P U$ positively affects $T T(b)$.

H3: ENJpositively affects TM(a) ENJpositively affects TT(b).

H4: PR negatively affects $T M(a) P R$ negatively affects $T T(b)$.

H5: SN positively affects TM(a) SN positively affects $T T(b)$.

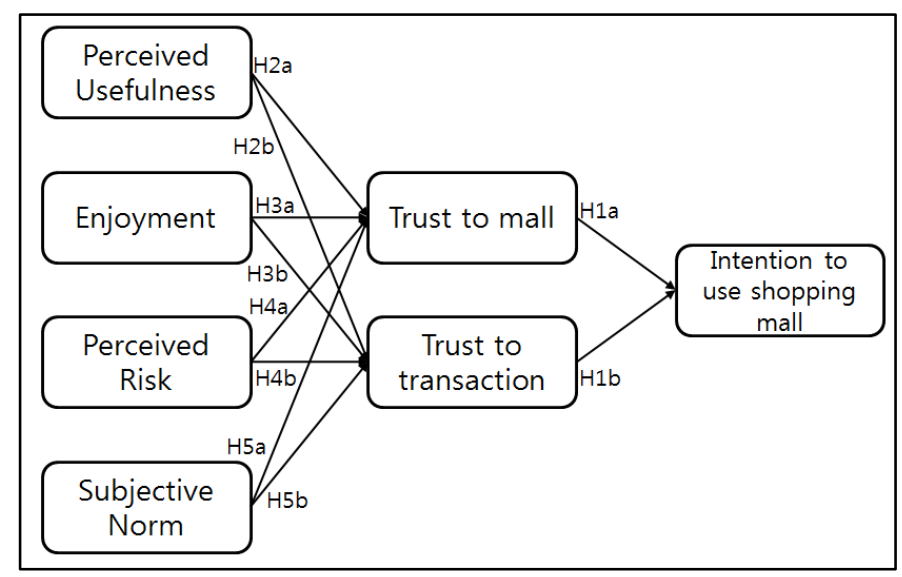

Figure 1. Research model 


\section{METHODOLOGY AND FINDINGS}

A survey $(n=584)$ was used to investigate the relationships. The items were based on findings of earlier studies ${ }^{7,10,12,13}$. We verified acceptable levels of reliability and validity using LISREL8.54. All hypotheses were provided except for $\mathrm{H} 1 \mathrm{~b}, \mathrm{H} 2 \mathrm{~b} \mathrm{H} 3 \mathrm{~b}$. This may have been due to differences in individual preferences as regards transaction. Surprisingly, TT has no relationship with INT, this may be due to more direct effect of TT on INT.

Table 1. Hypothesis test

\begin{tabular}{ccc}
\hline Hypothesis & Standardized Coefficient & Results \\
\hline H1a & $0.51^{*}$ & Yes \\
H1b & -0.01 & No \\
H2a & $0.21^{*}$ & Yes \\
H2b & 0.07 & No \\
H3a & $0.19^{* * *}$ & Yes \\
H3b & 0.19 & No \\
H4a & $-0.13^{* * *}$ & Yes \\
H4b & $-0.17^{* *}$ & Yes \\
H5a & $0.19^{* *}$ & Yes \\
H5b & $0.28^{* * *}$ & Yes \\
\hline Note: $* * * p<.001, * * p<.01, * p<.05 ;$ GFI $=0.85, \mathrm{NFI}=0.93, \mathrm{CFI}=0.93$, \\
RMSEA $=0.088$ & &
\end{tabular}

\section{Conclusions}

The online shopping mall operators should recognize the existence of two trusts. We revealed the role of trust as a mediator and factors in other models affect trust we proposed. We concluded that operators have to configure their malls well to enhance TM rather than to enhance transaction. Except for SN, PR, all antecedents only affect TT and TM has a significant effect on INT. However, this does not mean the less importance of a secure transaction. Due to the development of online transaction security, consumers may start to focus more on shopping mall. If malfunction happens, consumers may get back to concentrate on shopping all. The limitation of this study is no empirical data of other ethnic groups. The future research may complement the limitation. 


\section{REFERENCE}

[1] Korea Consumer Agency, 2010 Research on consumer injury in E-commerce, 2011.

[2] D. Gefen, E. Karahanna, and D.W. Straub, Trust and TAM in online shopping: An integrated model. MIS Quarterly, 27(1), p51-90, 2003.

[3] R.M. Morgan, and S.D. Hunt, The commitment and trust theory of relationship marketing. Journal of Marketing, 58(3), p20-38, 1994. http://dx.doi.org/10.2307/1252308.

[4] A. Noteberg, E. Christiaanse, and P. Wallage, Consumer trust in electronic channels: the impact of electronic commerce assurance on consumers' purchasing likelihood and risk perceptions. E-Service Journal, 2(2), p46-67, 2003. http://dx.doi.org/10.1353/esj.2003.0014.

[5] D.J. Kim, D.L. Ferrin, and H.R. Rao, A trust-based consumer decision-making model in electronic commerce: The role of trust, perceived risk, and their antecedents. Decision Support Systems, 44(2), p544-564, 2008. http://dx.doi.org/10.1016/j.dss.2007.07.001.

[6] A. Wong, and A. Sohal, An examination of the relationship between trust, commitment and relationship quality. International Journal of Retail \& Distribution Management, 30(1), p34-50, 2002. http://dx.doi.org/10.1108/09590550210415248.

[7] P.A. Pavlou, Consumer acceptance of electronic commerce: Integrating trust and risk with the technology acceptance model. International Journal of Electronic Commerce, 7(3), p69-103, 2003.

[8] H.H. Chang, and S.W. Chen, The impact of online store environment cues on purchase intention trust and perceived risk as a mediator. Online Information Review, 32(6), 818-841, 2008. http://dx.doi.org/10.1108/14684520810923953.

[9] B.J. Corbitt, and T. Than, Trust and e-commerce: A study of consumer perceptions. Electronic Commerce Research and Applications, 2(3), 203-215, 2003. http://dx.doi.org/10.1016/S1567-4223(03)00024-3.

[10] I. Ajzen, and M. Fishbein, Understanding Attitudes and Predicting Social Behavior. Englewood Cliffs, NJ: Prentice-Hall, 1980.

[11] D.S. Johnson, Achieving customer value from electronic channels through identity commitment, calculative commitment, and trust in technology. Journal of Interactive Marketing, 21(4), p2-22, 2007. http://dx.doi.org/10.1002/dir.20091.

[12] F.D. Davis, Perceived usefulness, perceived ease of use, and user acceptance of information technology. MIS Quarterly, 13(3), p319-340, 1989. http://dx.doi.org/10.2307/249008.

[13] J. Fitzmaurice, Incorporating consumers' motivations into the theory of reasoned action. Psychology \& Marketing, 22(11), p911-929, 2005. http://dx.doi.org/10.1002/mar.20090. 